\title{
NCK2 wt Allele
}

National Cancer Institute

\section{Source}

National Cancer Institute. NCK2 wt Allele. NCI Thesaurus. Code C52408.

Human NCK2 wild-type allele is located in the vicinity of $2 q 12$ and is approximately $149 \mathrm{~kb}$ in length. This allele, which encodes cytoplasmic protein NCK2, plays a role in both cytoskeletal reorganization and the regulation of growth factor receptor signal transduction. 